\title{
Silica-Alumina-Supported Amine Catalysts for C-C Bond Formations
}

silica-alumina support

Michael addition

nitroaldol reaction
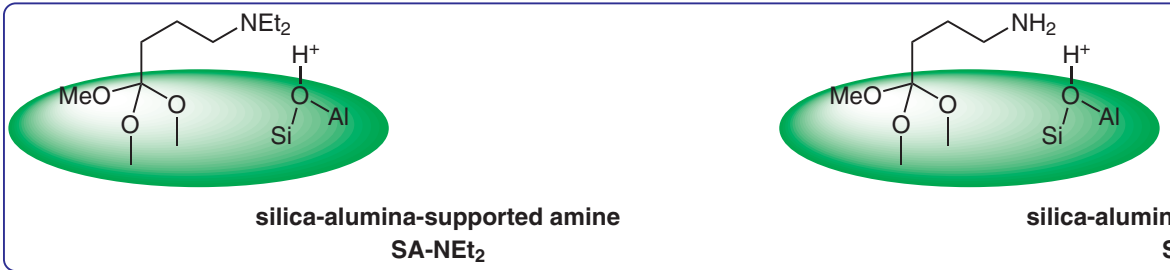

cyanoethoxycarbonylation<smiles>[R]C([2H])=O</smiles>

1<smiles></smiles><smiles></smiles>
$\mathrm{R}^{3}=\mathrm{Me}, \mathrm{Ph}$<smiles>O=C[PH]</smiles>

$\mathrm{R}^{4}=\mathrm{Ph}, \mathrm{c}$-Hex, octyl
SA-NEt

silica-alumina-supported amine $\mathrm{SA}-\mathrm{NH}_{2}$<smiles>[R7]C([1H])(C#N)OC(=O)OCC</smiles>

3: $88-99 \%$ (12 examples) 2 (1.2 mol equiv) $\underset{\text { toluene, } 90^{\circ} \mathrm{C}, 3-24 \mathrm{~h}}{\stackrel{\mathrm{SA}-\mathrm{NEt}_{2}(9 \mathrm{~mol} \% \mathrm{~N})}{\longrightarrow}}$<smiles>CC(C)(C)CCCC#N</smiles>

6: 94-99\% (3 examples) $\mathrm{EWG}=\mathrm{CO}_{2} \mathrm{Et}, \mathrm{CO}_{2} \mathrm{Me}, \mathrm{CN}$

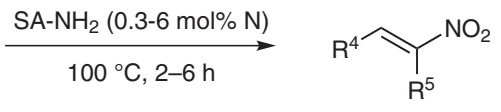

9: 88-99\% (4 examples)
Significance: Acid-base bifunctional silica-alumina-supported amine catalysts (SA-NEt 2 and SA$\mathrm{NH}_{2}$ ) were prepared and applied to the carboncarbon bond-forming reactions. Thus, SA-NEt 2 was prepared from an amorphous silica-alumina (SA) N633HN ( $\mathrm{SiO}_{2}$ : 66.5\%; $\mathrm{Al}_{2} \mathrm{O}_{3}: 25.1 \% ; 380$ $\mathrm{m}^{2} \mathrm{~g}^{-1}$ ) and 3-(diethylamino)propyl trimethoxysilane in toluene under reflux conditions. The cyanoethoxycarbonylation of $\mathbf{1}$ with $\mathbf{2}$ was catalyzed by $\mathrm{SA}-\mathrm{NEt}_{2}$ to give the corresponding carbonates $\mathbf{3}$ in 88-99\% yield (12 examples). The Michael reaction of $\mathbf{4}$ and $\mathbf{5}$ was performed with SA-NEt 2 to give the corresponding adducts 6 in 94-99\% yield (3 examples). SA- $\mathrm{NH}_{2}$-promoted the nitroaldol reaction of $\mathbf{7}$ and $\mathbf{8}$ to afford the nitroalkenes $\mathbf{9}$ in $88-99 \%$ yield (4 examples).
Comment: SA-NEt 2 and $\mathrm{SA}-\mathrm{NH}_{2}$ were reused four times without loss of catalytic activity in Michael and nitroaldol reactions. ${ }^{1} \mathrm{H}$ NMR spectroscopic analysis of the filtrate of the reaction mixture showed no leaching of amine compounds. $\mathrm{SA}-\mathrm{NEt}_{2}$ and $\mathrm{SA}-\mathrm{NH}_{2}$ were characterized by solid-state ${ }^{13} \mathrm{C}$ and ${ }^{29} \mathrm{Si}$ NMR spectroscopy, FT-IR spectroscopy, and elemental analysis. The authors emphasized that the co-existence of acidic and basic sites at the same solid surface without neutralization realized the catalyses with high efficiency. 